\title{
Study of the reuse of construction residues in concrete employed by blocks manufacture
}

\section{Estudo do reaproveitamento de resíduos de construção em concretos empregados na fabricação de blocos}
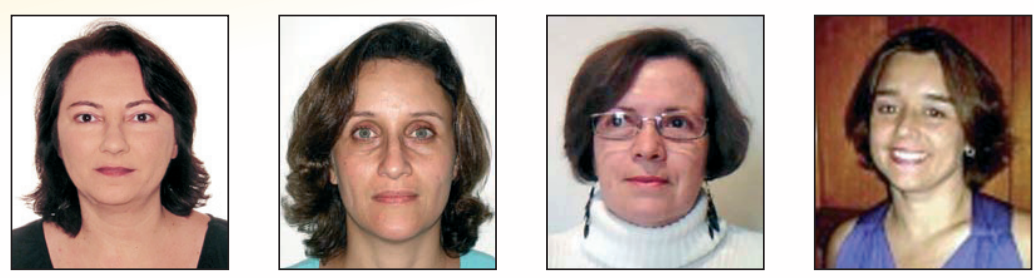

R. C. C. LINTZ a rosacclintz@ft.unicamp.br

A. E. P. G. A. JACINTHO ${ }^{b}$ ana@puc-campinas.edu.br

L. L. PIMENTEL c lialp@puc-campinas.edu.br

\section{A. GACHET-BARBOSA} gachet@ft.unicamp.br

\begin{abstract}
The use of construction and demolition waste (CDR) comes as an alternative for recycling, for costs reduction and for raw material. The CONAMA Resolution 307 (National Council for the Environment) establishes that all cities should find an environmentally correct destination to CDR. In this research the mechanical properties of the concrete containing CDR were analyzed aiming its use in the production of concrete blocks. Here, increasing percentages of aggregates of CDR with the same granulometry an substitute the natural aggregate, and then concrete blocks were molded. Tests were then performed in order to determine the compression strength according to NBR 12118:2007, at ages of 14 days and 28 days. It was noticed that the values resulting from the compression strength test were also influenced by the increasing substitution of CDR percentages to the mixture. This research discusses the great potential of using this material in substitution to the natural aggregates used in the production of concrete based materials such as blocks.
\end{abstract}

Keywords: alternative materials, materials and construction components, constructive processes.

\section{Resumo}

A utilização de resíduos de construção e demolição (RCD) apresenta-se como uma alternativa de reciclagem, de redução de custos e de matéria-prima. A Resolução 307 do CONAMA determina que todos os municípios devam dar uma destinação ambientalmente correta aos RCD. Nesta pesquisa foram analisadas as propriedades mecânicas do concreto contendo RCD objetivando seu emprego na fabricação de blocos de concreto. É realizada a substituição dos agregados naturais pelos agregados de mesma granulometria provenientes de RCD, em porcentagens crescentes, e moldados blocos de concreto. São realizados ensaios para a determinação da resistência à compressão segundo a NBR 12118:2007, aos 14 e 28 dias de idade. Os valores apresentados pelo ensaio de resistência à compressão são influenciados pelas porcentagens crescentes de RCD na mistura. Esta pesquisa aponta o grande potencial do aproveitamento desse material em substituição aos agregados naturais utilizados na fabricação de materiais à base de concreto como os blocos.

Palavras-chave: materiais alternativos, materiais e componentes da construção, processos construtivos.

\footnotetext{
Professora da Faculdade de Tecnologia - UNICAMP, rosacclintz@ft.unicamp.br, Rua Paschoal Marmo, 1888, Limeira -SP, Brasil, CEP $13484-332$

- Professora da Faculdade de Engenharia Civil - CEATEC - PUC-CAMPINAS, ana@puc-campinas.edu.br, Rod. Dom Pedro l, km 136, Parque das Universidades, Campinas-SP, Brasil, CEP 13086-300;

Professora da Faculdade de Engenharia Civil - CEATEC - PUC-CAMPINAS, lialp@puc-campinas.edu.br, Rod. Dom Pedro l, km 136, Parque das Universidades, Campinas-SP, Brasil, CEP 13086-300

d Professora da Faculdade de Tecnologia - UNICAMP, gachet@ft.unicamp.br, Rua Paschoal Marmo, 1888, Limeira -SP, Brasil, CEP $13484-332$
} 


\section{Introduction}

The construction industry is one of the oldest activities ever known and since the dawn of humanity it was performed by hand, generating as sub-product a large amount of waste of various natures. It is also responsible for the excessive consumption of natural resources from non-renewable sources (Boldrin et al. [1]).

However this is one of the sectors that has great potential to absorb the waste. The recycling of construction waste as aggregates is an important alternative for reducing the environmental impact and for its preservation (Oliveira et al. [2], and Helene Levy [3], John [4]).

The use of construction and demolition waste in the manufacture of concrete blocks and mortar settlement is technically feasible and can be used in the construction of popular housing (Farias et al. [5]). Bastos et al. [6] also emphasize the use of CDW for paving new roads.

According to Ajdukiewicz and Kliszczewics [7] after recycling waste coming from the reconstruction of roads and bridges made of reinforced concrete and prestressed, they are used as aggregates in Eastern Europe.

In conformity to studies by Butler et al. [8] on building blocks of concrete with recycled aggregates it can be noted that the blocks with recycled aggregates had lower levels of density and higher rates of absorption and voids compared to values obtained by the reference blocks.

Fonseca Junior and [9] noted that recycled aggregates with maximum dimension less than $9.5 \mathrm{~mm}$ can be used not only in concrete with plastic consistency, but in concrete artefacts with zero abatement and good resistance, as well as low consumption of cement. According to Boldrin et al. [1] increasing substitution of natural aggregates by recycled aggregates from construction, employed in the manufacture of concrete blocks, affects the consistency of the mixtures, with a decrease in fluidity. The fine recycled aggregate had higher water absorption than the traditional fine aggregate, affecting directly the mechanical properties of concretes. Concrete with percentages up to $60 \%$ of construction waste seems to be most suited for use in the manufacture of concrete blocks.

According to Dafico et al. [10] the concrete blocks produced with recycled construction aggregates have a very large variability concerning the results of compression strength; however it was observed that the best mixture is when the cement is mixed with the aggregate in dry saturated surface, followed by the introduction of mixing water with air-incorporating additives.

Resolution no 307 of CONAMA (National Council of Environment) establishes guidelines, criteria and procedures for the management of construction waste in order to provide social, economic and environmental benefits. On August 16, 2004, Resolution no 348 of CONAMA amended art. 3, item IV, of CONAMA Resolution no 307

Considering that such wastes represent a significant percentage of solid waste generated in urban areas and that the disposal of construction waste in inappropriate places contributes to the degradation of environmental quality, the municipalities are responsible for the environmentally sound management and disposal of such wastes seeking effective reduction of environmental impacts. According to Resolutions no 307 and no 348 construction waste are classified into four classes:
I - Class A - reusable or recyclable waste like aggregates, such as: a) from construction, demolition, renovations and paving repairs and other infrastructure works, including soil from earthworks;

b) from construction, demolition, renovations and repairs of buildings: ceramic components (bricks, blocks, tiles, flooring boards, etc..), mortar and concrete;

c) from manufacturing process and / or demolition of pre-cast concrete (blocks, pipes, curbs, etc..) produced in construction sites;

II - Class B - recyclable waste to other destinations, such as plastics, paper / cardboard, metal, glass, wood and others;

III - Class C - wastes for which no economically feasible technologies or applications have been developed that enable recycling / recovery, such as products from the cast;

IV - Class D - hazardous waste from the construction process, such as paints, solvents, oils and other contaminated or those harmful to health coming from demolition, renovations and repairs of radiology clinics, and other industrial facilities as well as tiles and other objects and materials containing asbestos or other products harmful to health .

In Brazil, recycling companies separate the contaminants such as wood, plastics and nonferrous metals from the construction waste, by hand. Usually the recycled aggregate is used as basis for construction paving and sealing concrete blocks. Countries like Japan, England and Holland partially or completely replace natural aggregates by recycled ones, due to higher levels of contaminants removal of construction waste (Angulo and John [11]).

\subsection{Agreement}

In this work we analyzed the incorporation of construction and demolition waste (CDW) in concrete used in the manufacture of hollow blocks of plain concrete masonry units. The aim of this study was to evaluate the influence of increasing substitution of CDW by mass of natural aggregates in the mixture of concrete, the mechanical properties of concrete blocks according to the specifications of Brazilian standards.

\section{Materials and experimental program}

All materials used in the experimental part of the research were provided by the companies in the metropolitan region of Campinas, such as CPV-ARI Portland cement, sand of quartz origin, basaltic gravel and recycled construction waste as aggregates.

At the recycling plant, CDW passed through a screening process to remove impurities such as iron, rubber, plastic and organic material [Figure 1], before being crushed and separated into different particle size. Figures 2 and 3 show the fine and coarse recycled aggregates respectively, used in this research.

The CDW chosen to be used was that material coming from waste cement composites (mortars and concretes) called "gray."

\section{Physical Aggregates Characterization}

Tests of physical characterization of aggregates were done, such as: determining the density according to the specifications of NBRNM52:2009 [12] for fine aggregates and NBRNM53:2009 [13] for the coarse aggregates, determination of bulk density of the aggregates as specifications in NBRNM45:2006 [14], and classification of aggregates according to 


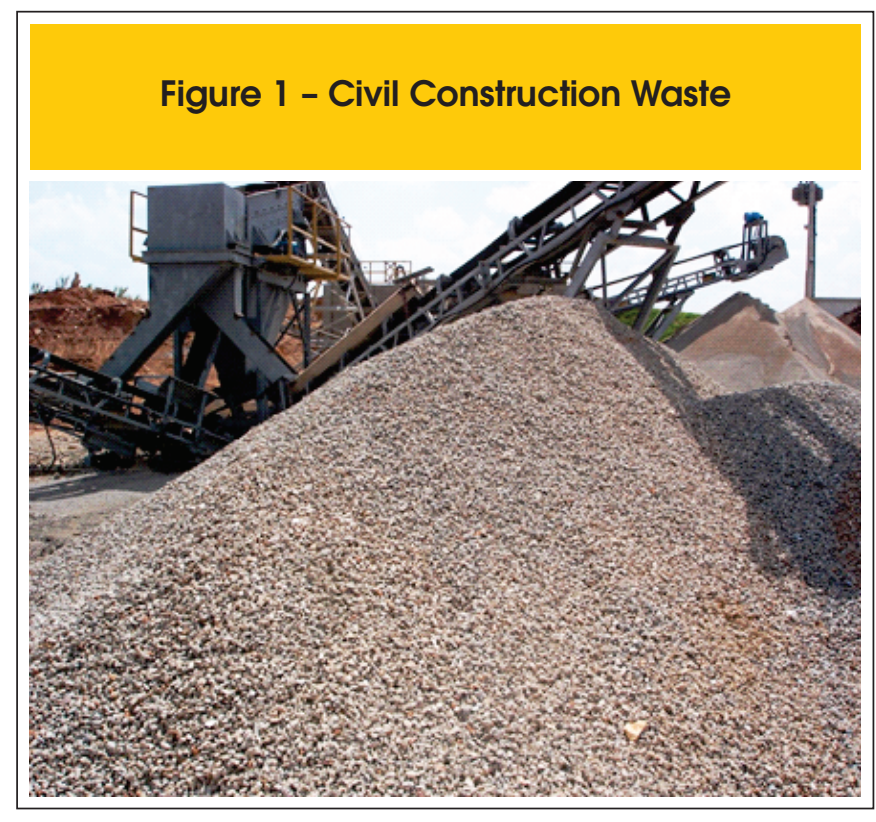

the granulometric composition as seen on NBR7211:2009 [15]. The tests results obtained are described in Table 1.

\section{Selection of dosages of Concrete with and without CDW}

The mix proportions of concrete, in mass, selected for this study was: 1:3,5:3,0:2,5:0,80 (cement: fine sand, medium sand: gravel: water). From the mix proportion considered as reference concrete were produced with increasing incorporation of CDW in substitution of aggregates in the following proportions:

E0 - reference concrete mixture;

E1 - a mix of concrete with $20 \%$ replacement of natural aggregates by CDW;

E2 - a mix of concrete with $50 \%$ replacement of natural

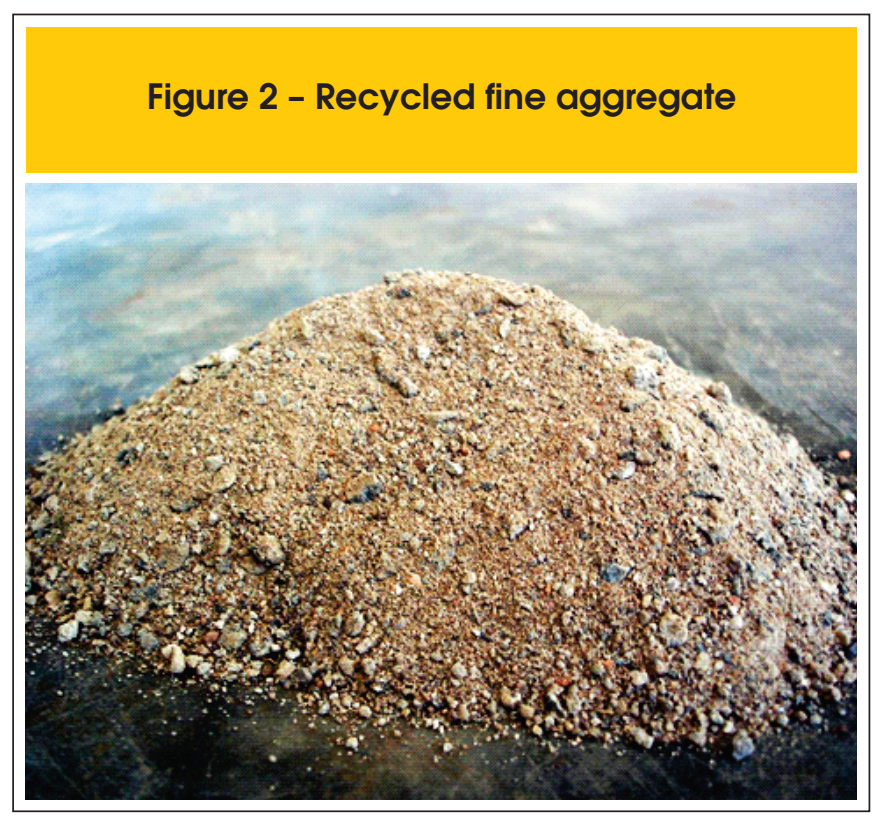

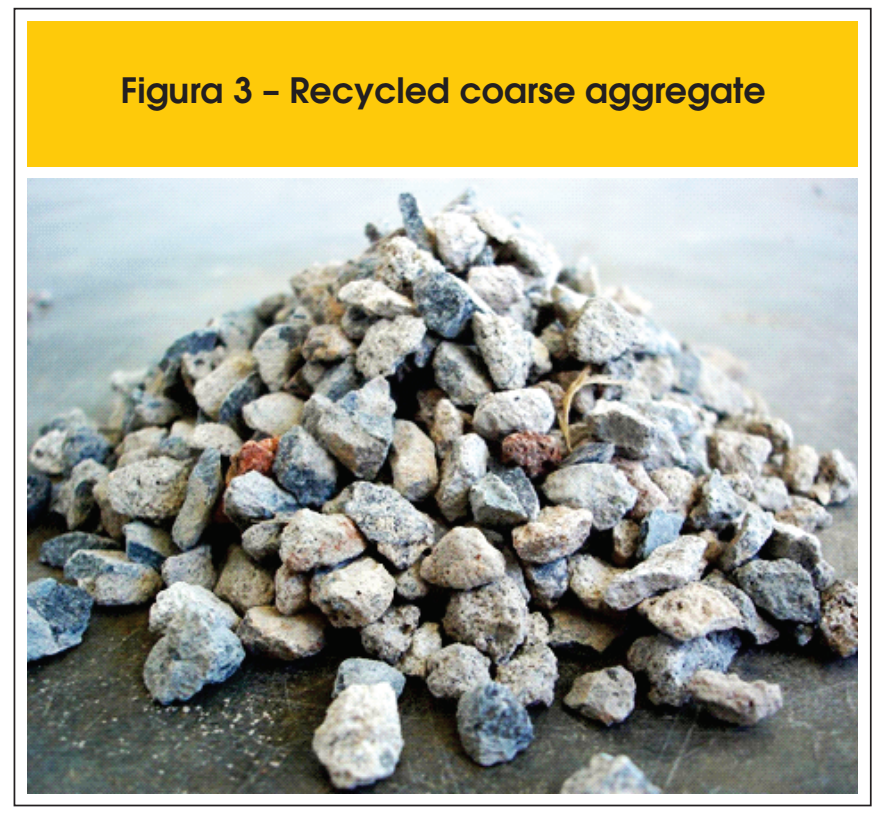

aggregates by CDR;

E3 - a mix of concrete with $80 \%$ replacement of natural aggregates by CDR;

E4 - a mix of concrete with $100 \%$ replacement of natural aggregates by CDR;

Cylindrical concrete specimens were moulded, with dimensions $10 \times 20 \mathrm{~cm}$, for performing the following tests: determination of compressive strength (NBR5739:2007 [16]), tensile strength by diametrical compression (NBR7222:1994 [17]) and determination of water absorption by immersion (NBR9778:2009 [18]). Concrete blocks were also made using vibro - presses. The size of concrete blocks selected were $14 \times 19 \times 39 \mathrm{~cm}$ (Figure 4). The blocks were submitted to tests to determine the compressive strength and water absorption capacity, as in NBR12118:2007 [19].

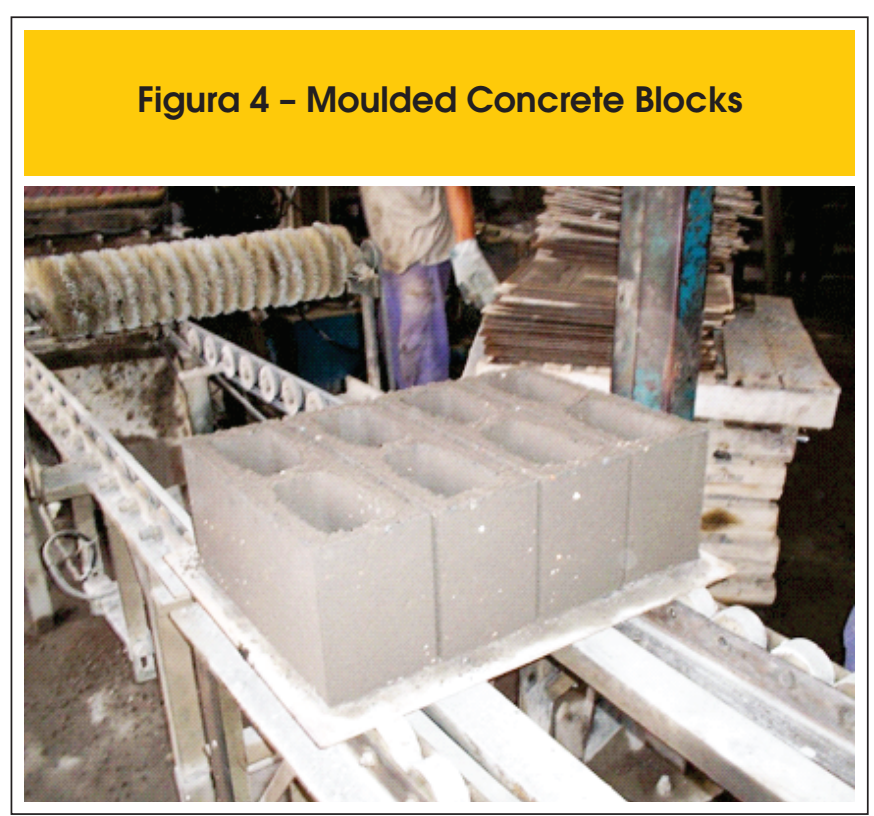




\section{Table 1 - Physical characterization of aggregates}

\begin{tabular}{|c|c|c|c|c|c|}
\hline Material & $\begin{array}{c}\text { Specific } \\
\text { mass }(\mathrm{Kg} / \mathrm{l})\end{array}$ & $\begin{array}{c}\text { Unitary } \\
\text { Mass (Kg/l) }\end{array}$ & $\begin{array}{l}\text { Maximum dimension } \\
\text { Feature }(\mathrm{mm})\end{array}$ & $\begin{array}{l}\text { Fineness } \\
\text { Modulus }\end{array}$ & $\begin{array}{l}\text { Granulometric } \\
\text { Qualification }\end{array}$ \\
\hline $\begin{array}{l}\text { Natural } \\
\text { Fine } \\
\text { aggregate }\end{array}$ & 2,62 & 1,47 & 2,4 & 1,93 & $\begin{array}{l}\text { zone } 2 \\
\text { fine sand }\end{array}$ \\
\hline $\begin{array}{l}\text { Natural } \\
\text { Fine } \\
\text { aggregate }\end{array}$ & 2,90 & 1,63 & 4,8 & 2,74 & $\begin{array}{c}\text { zone } 3 \\
\text { medium sand }\end{array}$ \\
\hline $\begin{array}{c}\text { Natural } \\
\text { Coarse } \\
\text { aggregate }\end{array}$ & 2,86 & 1,64 & 9,5 & 6,67 & gravel 0 \\
\hline $\begin{array}{l}\text { Natural } \\
\text { Fine } \\
\text { aggregate }\end{array}$ & 2,34 & 1,33 & 4,8 & 2,38 & $\begin{array}{c}\text { zone } 3 \\
\text { recycled } \\
\text { medium sand }\end{array}$ \\
\hline $\begin{array}{c}\text { Natural } \\
\text { Coarse } \\
\text { Aggregate }\end{array}$ & 2,55 & 1,46 & 9,5 & 3,36 & $\begin{array}{c}\text { recycled } 0 \\
\text { gravel }\end{array}$ \\
\hline
\end{tabular}

The mixture was made in intermittent concrete mixer of inclined axis (NBR5738:2008 [20]), and later the specimens were moulded on the vibrating table and cured, submerged in a tank of saturated water with lime, for 28 days, according to the specifications of NBR5738:2008 [20]. After curing, the cylindrical specimens were rectified for execution of the tests and the blocks capped.

\section{Results and discussion}

Figures 5 and 6 show the results obtained from tests for compres-

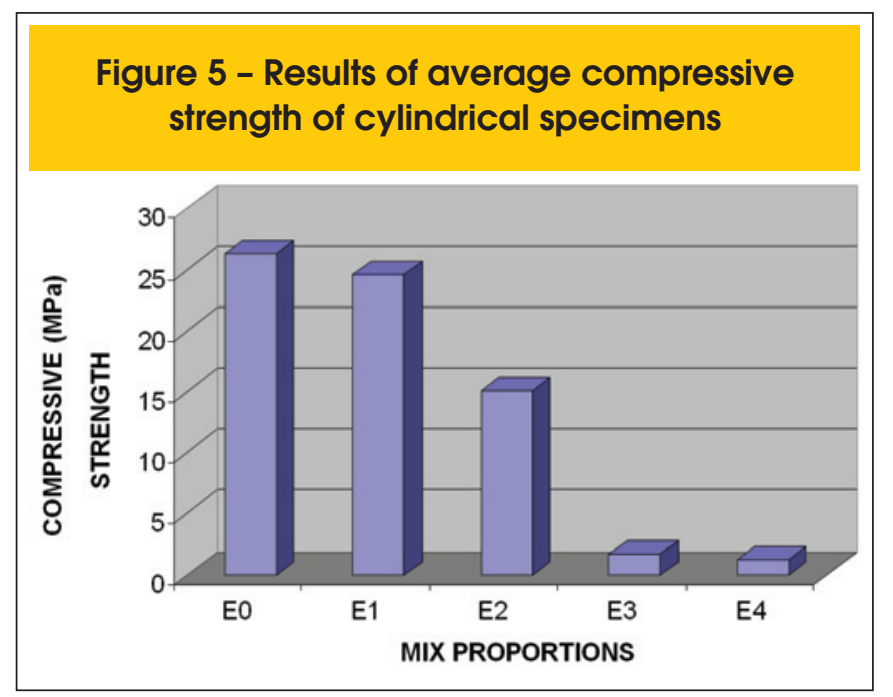

sive strength and tensile strength by diametrical compression for the cylindrical specimens, at 28 days. Figures 7 and 8 show the results from the compression tests of concrete blocks, at 14 and 28 days. Figures 9 and 10 show the rates of water absorption by immersion for the cylindrical specimens and values of water absorption capacity of concrete blocks, respectively. Both absorption tests were performed at 28 days of curing.

Through the analysis of data from the characterization tests, it was observed that the natural aggregates have higher specific and single densities than the recycled aggregates, confirming the results

\section{Figure 6 - Results of tensile strength by average diametrical compressive of cylindrical specimens}

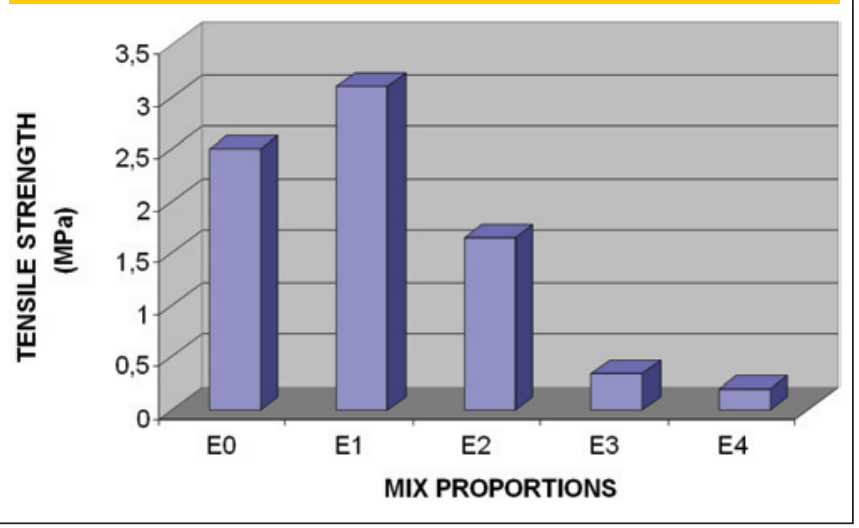




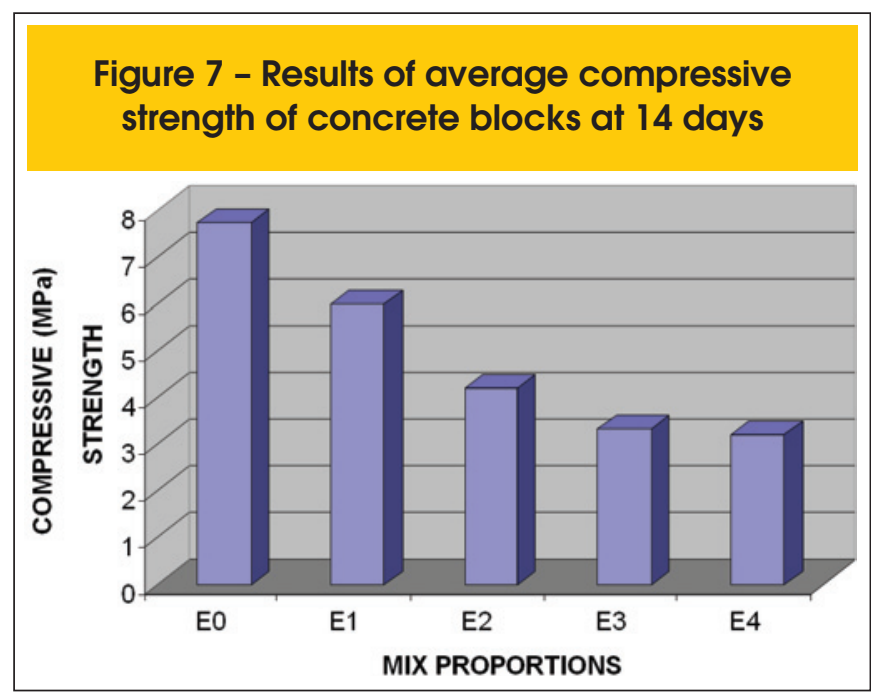

Figure 8 - Results of average compressive strength of concrete blocks at 28 days

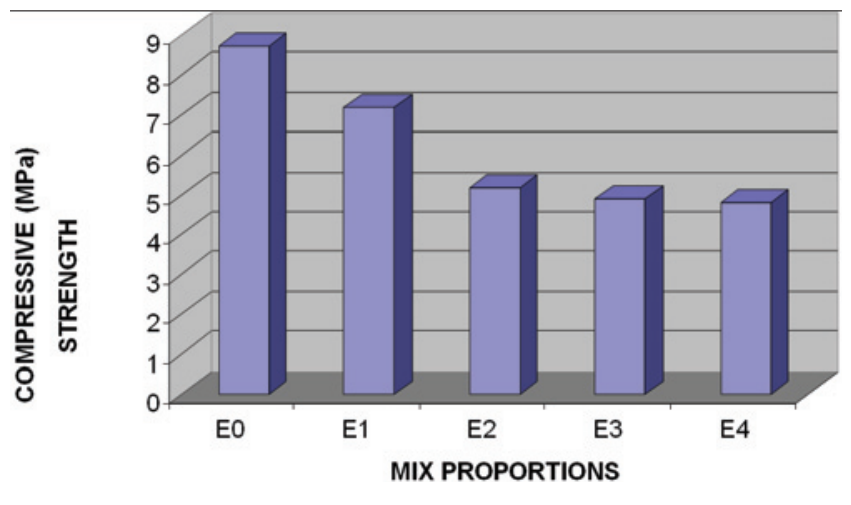

found by researchers Boldrin et al. [1]; Lintz and Simonetta [21] for these physical characteristics.

As for the compressive strength of the concrete specimens, compositions E1, E2 accounted for $94 \%$ and $58 \%$ of the value given for the reference mixture (E0). For the other mixtures the fall for this property was substantial.

For the tensile strength by diametrical compression, compositions $\mathrm{E} 0, \mathrm{E} 1$ and E2 have values within the limits of resistance of concrete blocks.

As for the compressive strength of concrete blocks, the NBR6136:2007 [22] classifies simple concrete blocks masonry, into four classes, as shown in Table 2, being classified for use in: Class A - With structural function, for use in masonry elements above or below ground level;

Class B - With structural function, for use in masonry elements above ground level;

Class C - With structural function ,for use in masonry elements above ground level;

Class D - No structural function, for use in masonry elements above ground level;

\section{Figure 9 - Test results of water absorption by immersion of specimens}

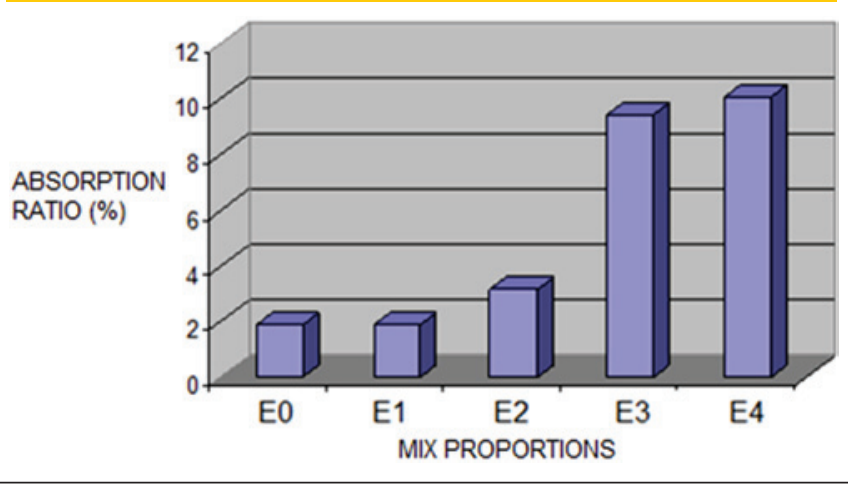

Figure 10 - Test results of water absorption of concrete blocks

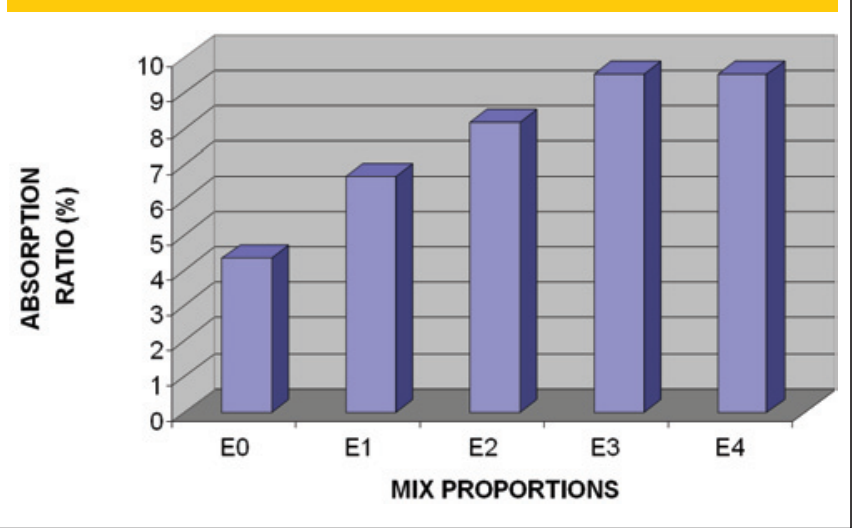

It can be observed that for all concrete mixes used in the manufacture of the blocks the compressive strength values are within the limitations of the Brazilian standard for use as part of the masonry. The blocks executed with the mix concrete reference $\mathrm{E} 0$ and the mix concrete $\mathrm{E} 1$, showed resistance above $6 \mathrm{MPa}$ at 28 days, being classified as "Class A" and the others meet the strength characteristics of "class B".

\section{Table 2 - Requirements for characteristic compression strength of concrete blocks (NBR6136)}

\begin{tabular}{cc} 
Class & Strength Feature $\left(f_{b k}\right) M P a$ \\
A & $\geqslant 6,0$ \\
$B$ & $\geqslant 4,0$ \\
C & $\geqslant 3,0$ \\
D & $\geqslant 2,0$ \\
\hline
\end{tabular}




\begin{tabular}{|c|c|c|}
\hline \multicolumn{3}{|c|}{$\begin{array}{l}\text { Table } 3 \text { - Results of Multiple Comparison Tes } \\
\text { for compression strength at } 14 \text { days of age }\end{array}$} \\
\hline \multicolumn{3}{|c|}{ Multiple Comparison Test } \\
\hline Mix & Average & $\begin{array}{l}\text { Homogeneous } \\
\text { Groups }\end{array}$ \\
\hline E 4 & 4,165 & $x$ \\
\hline E 3 & 3,4083 & $x$ \\
\hline E 2 & 4,180 & $x$ \\
\hline E 1 & 6,07 & $x$ \\
\hline E 0 & 7,742 & $x$ \\
\hline
\end{tabular}

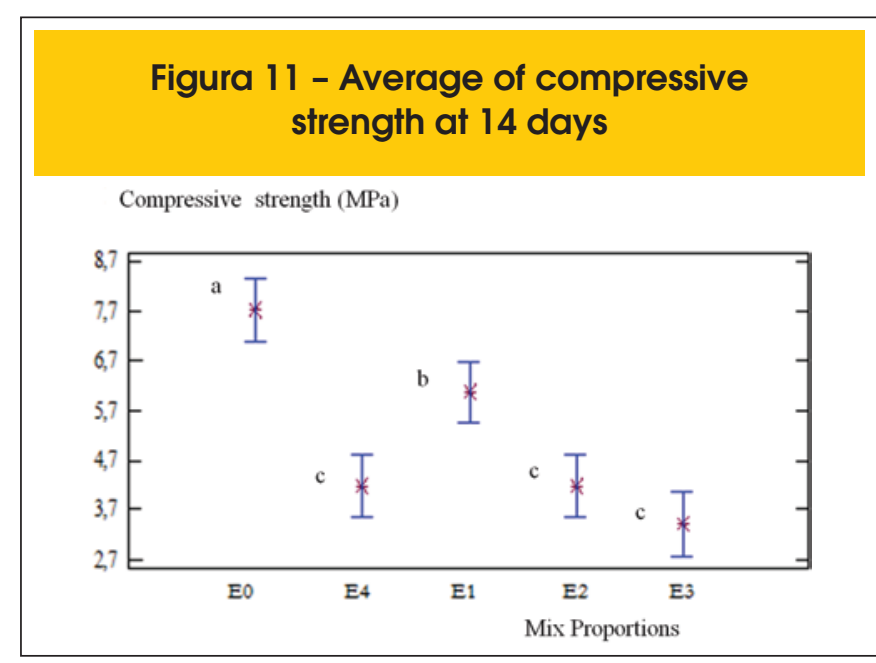

The results of simple compressive strength at 14 days were analyzed statistically through Analysis of Variance - ANOVA, depending on the percent replacement factor of natural aggregate by CDW. At 14 days of age (R14), the percentage factor replacement is statistically significant at $95 \%$ significance level ( $p$ Value $=0.0025$ ).

Through the multiple comparison procedure [Table 3] applied depending on the percentage factor replacement, there are three statistically different groups. These groups are indicated by letters $a, b$ and $c$ in Figure 11, which shows the average strength of the blocks at 14 days.

The results of compressive strength at 28 days were analyzed statistically using analysis of variance - ANOVA, depending on the percentage factor replacement of natural aggregate by CDW.

At 28 days of age (R28), the percentage factor replacement is statistically significant at $95 \%$ significance level ( $p$ Value $=0.0025)$.

Through the multiple comparisons procedure [Table 4] applied depending on the percentage of substitution, there are three statistically different groups. These groups are indicated by letters $a, b$ and $\mathrm{c}$ in Figure 12, which shows the average strength of the blocks at 28 days.
Table 4 - Results of Multiple Comparison Test for compression strength at 28 days of age

\begin{tabular}{|ccccc|} 
Mix & \multicolumn{3}{c|}{$\begin{array}{c}\text { Multiple Comparison Test } \\
\text { Average }\end{array}$} & $\begin{array}{c}\text { Homogeneous } \\
\text { Groups }\end{array}$ \\
E 4 & 4,771 & X & & \\
E 3 & 4,936 & $X$ & & \\
E 2 & 5,244 & $X$ & & \\
E 1 & 7,181 & & $X$ & \\
E 0 & 8,751 & & & $X$ \\
\hline
\end{tabular}

\section{Figure 12 - Average of compressive strength at 28 days}

Compressive strength (MPa)

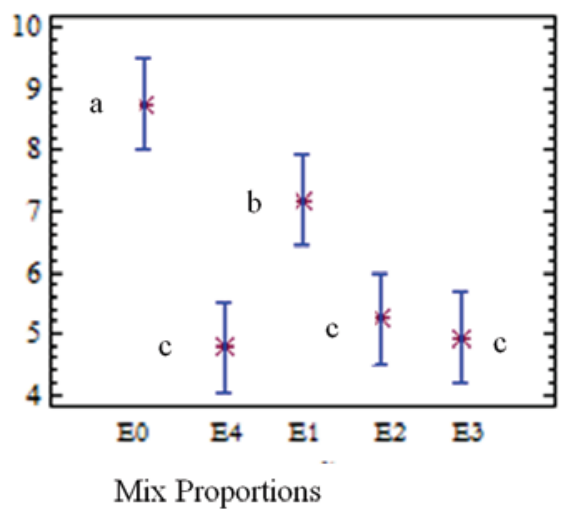

By the statistical analysis with multiple comparison of compressive strength results of concrete blocks, presented in Tables 3 and 4 and Figures 11 and 12, it is observed that for traits with replacement of $50 \%, 80 \%$ and $100 \%$ of natural aggregates by CDW, the compressive strength values do not differ statistically, among each other, with less than $5 \%$ significance level, at 14 days and also at 28 days of age.

For the cylindrical concrete specimens the compressive strength limits the incorporation of CDW in $50 \%$.

The substitution of $50 \%$ of natural aggregates for recycled construction waste allowed the production of blocks with compressive strength which meets the specification of NBR6136:2007[22] for B class.

Concerning water absorption of concrete blocks, according to NBR6136: 2007 [22], the content accepted for concrete hollow blocks using regular aggregates must be less than or equal to $10 \%$. Therefore it is noted that for all doses studied on concrete blocks this question is answered. 


\section{Conclusions}

For concrete mixes, with and without building waste, used in the manufacture of blocks, studied in this research, it was noted that: The test results of compressive strength on cylindrical specimens have shown that it is feasible to substitute partially natural aggregates by recycled CDW in the manufacture of concrete;

- The test results of compressive strength on cylindrical specimens have shown that it is feasible to substitute partially natural aggregates by recycled CDW in the manufacture of concrete;

- The water absorption of concrete blocks and specimens increase according to the growing incorporation of recycled aggregates CDW, but both meet the limits of Brazilian standard for all the doses studied;

- The test results of compressive strength of the blocks prove the technical feasibility of the product for use as an element in the masonry construction industry.

\section{Acknowledgements}

The authors acknowledge the human and material support provided by the Laboratory of Building Materials and Structures, College of Civil Engineering, PUC-Campinas, where the tests were performed.

\section{Bibliography}

[01] BOLDRIN, A. J.; MACHADO, R. L.; CAMPOS, M. A.; LINTZ, R. C. C. Estudo das Propriedades Mecânicas do Concreto com Resíduos de Construção e Demolição Empregados na Produção de Blocos de Concreto. In: Congresso Brasileiro do Concreto, $48^{\circ}$, Rio de Janeiro, 2006, Anais, 48CBC0237.

[02] OLIVEIRA, D.F.; SANTOS, V.S.; LIRA, H.L.; MELO, A.B.; NEVES, G.A. Durabilidade de compósitos de concreto de cimento portland produzidos com agregados reciclados da construção civil. Revista Eletrônica de Materiais e Processos, v.1, n.2, 2006; p.30-36.

[03] LEVY, S. M.; HELENE, P.R.L. Utilização de Agregados Reciclados de Concreto Para Produção de Novos Concretos. In: Congresso Brasileiro do Concreto, $48^{\circ}$, Rio de Janeiro, 2006, Anais, $47 \mathrm{CBC} 0488$.

[04] JOHN, V. M.; Reciclagem de resíduos na construção civil - contribuição à metodologia de pesquisa e desenvolvimento, São Paulo, 2000, Tese (livre docência) - Escola Politécnica, Universidade de São Paulo, $102 \mathrm{p}$.

[05] FARIAS, R. S.; LIMA, F. B.; VIEIRA G. L.; BARBOZA, A. S. R.; GOMES, P. C. C. Análise de propriedades de resistência à compressão e módulo de elasticidade em prismas de blocos de concreto produzidos com agregados reciclados de resíduos de construção e demolição. In: Congresso Brasileiro do Concreto, $47^{\circ}$, Pernambuco, 2005, Anais, 47CBC0398.

[06] BASTOS, G. D. A.; BASTOS, I. D. A.; FIOR, L.; HILDEBRAND, L.; CERRI, J. A.; ARAÚJO M. S.
Desenvolvimento em escala industrial de composições para blocos de solo-cimento utilizando fração cerâmica de entulho da construção civil - Um estudo de caso. In: I Conferência Latino-Americana de Construção Sustentável. X ENCONTRO NACIONAL DE TECNOLOGIA DO AMBIENTE CONSTRUIDO, São Paulo, 2004, Anais, v. 1. p. 18-21.

[07] AJDUKIEWICZ, A. e KLISZCZEWICS, A. Influence of recycled aggregates on mechanical properties of HS/HPC. Cement and Concrete Composites, v.24, 2002; p. 269-279.

[08] BUTTLER, A. M.; PRADO, D. M.; CORRÊA, M. R. S. (3); RAMALHO, M. A. Blocos Estruturais de Concreto Com Agregados Reciclados de Concreto Caracterização das Propriedades Físicas. In: XI Encontro Nacional de Tecnologia do Ambiente Construído, Florianópolis, 2006, Anais, p. 3540-49.

[09] FONSECA, F. B.; JUNIOR E. F. M. Desempenho Estrutural de Paredes de Alvenaria de Blocos de Concreto Com Agregados Reciclados de Rejeitos de Construção e Demolição. In: Congresso Brasileiro do Concreto, $44^{\circ}$, Belo Horizonte, 2002, Anais.

[10] DAFICO, D.A.; SILVA, A.L.A.; CALIXTO, R.J Blocos de Concreto a Partir de Entulho de Construções: Influência do Modo de Preparo das Misturas. In: Congresso Brasileiro do Concreto, $47^{\circ}$, Recife, 2005, Anais, 47CBC0400.

[11] ANGULO, S. C. ; JOHN, V. M. . Normalização dos agregados graúdos de resíduos de construção e demolição reciclados para concretos e a variabilidade. In: IX Encontro Nacional de Tecnologia do Ambiente Construído, 2002, Foz do Iguaçu. IX Encontro Nacional de Tecnologia do Ambiente Construído, Foz do Iguaçu, 2002, Anais, p. 1613-1624.

[12] ASSOCIAÇÃO BRASILEIRA DE NORMAS TÉCNICAS. Agregado miúdo - Determinação de massa específica e massa específica aparente NBRNM52, Rio de Janeiro, 2009.

[13] ASSOCIAÇÃO BRASILEIRA DE NORMAS TÉCNICAS. Agregado graúdo - Determinação de massa específica, massa específica aparente e absorção de água - NBRNM53, Rio de Janeiro, 2009.

[14] ASSOCIAÇÃO BRASILEIRA DE NORMAS TÉCNICAS. Agregados - Determinação da massa unitária e do volume de vazios - NBRNM45, Rio de Janeiro, 2006.

[15] ASSOCIAÇÃO BRASILEIRA DE NORMAS TÉCNICAS. Agregado para concreto - Especificação - NBR 7211, Rio de Janeiro, 2009.

[16] ASSOCIAÇÃO BRASILEIRA DE NORMAS TÉCNICAS. Concreto - Ensaio de compressão de corpos-de-prova cilíndricos - NBR5739, Rio de Janeiro, 2007.

[17] ASSOCIAÇÃO BRASILEIRA DE NORMAS TÉCNICAS. Argamassa e concreto - Determinação da resistência à tração por compressão diametral de corpos-de-prova cilíndricos - NBR7222, Rio de Janeiro, 1994. 
[18] ASSOCIAÇÃO BRASILEIRA DE NORMAS

TÉCNICAS. Argamassa e concreto endurecidos -

Determinação da absorção de água, indice de vazios

e massa específica - NBR9778, Rio de Janeiro, 2009.

[19] ASSOCIAÇÃO BRASILEIRA DE NORMAS

TÉCNICAS. Blocos vazados de concreto simples para alvenaria - Métodos de ensaio - NBR12118, Rio de Janeiro, 2007.

[20] ASSOCIAÇÃO BRASILEIRA DE NORMAS TÉCNICAS. Concreto - Procedimento para moldagem e cura de corpos-de-prova - NBR5738, Rio de Janeiro, 2008.

[21] LINTZ, R.. C. C.; SIMONETTI, F. C. incorporação de resíduos de construção em compósitos de cimento empregados na fabricação de blocos. In: Congresso Brasileiro de Engenharia e Ciência dos Materiais CBECiMat, $18^{\circ}$, Porto de Galinhas, 2008, Anais, p. 213-222.

[22] ASSOCIAÇÃO BRASILEIRA DE NORMAS TÉCNICAS. Blocos vazados de concreto simples para alvenaria - Requisitos - NBR6136, Rio de Janeiro, 2007. 